\title{
Impact of Government Expenditure on Economic Growth: Evidence from Nigeria
}

\author{
Bashir Bappahyaya, \\ School of Basic and Remedial Studies, \\ Gombe State University, Gombe, Nigeria \\ Fada K. Abiah, \\ Department of Business Administration, \\ Gombe State University, Gombe, Nigeria \\ Farida Bello, \\ Department of Economics, \\ Gombe State University, Gombe, Nigeria
}

\begin{abstract}
This study seeks to explain the impact of government expenditure on economic growth in Nigeria using time series data from 1970 - 2017. Secondary data were sourced from Central Bank of Nigeria and World Bank. The study applied a modified version of endogenous growth model using Autoregressive distributed lag model. The adopted model was fitted with six variables- capital stock, labour force, capital expenditure, recurrent expenditure, inflation and trade openness. The study employed ADF-unit root test, Phillips-Perron test and Pairwise Granger causality test. All the variables used were found to be integrated at first difference except labour and inflation and a stable long run equilibrium relationship exist between the dependent and independent variables. Empirical findings revealed that two variables: capital and recurrent are statistically significant and hence these are the significant variables in explaining the impact of government expenditure on economic growth. The Granger causality test demonstrates a unidirectional causality from government expenditure to economic growth, in validation of Keynesian theory. In line with above, the study recommends among others that: government should intensify effort to ensure resources are properly managed and invested in productive sectors so as to foster economic growth.
\end{abstract}

Keywords: ARDL, Government expenditure, Nigeria, Economic Growth 


\section{Introduction}

The crucial need for government to participate in the economy can be seen from the need to enforce contracts, protect property, and develop infrastructure (Abdullah, 2000; Njoku \& Nwaeze, 2014). The role of government in economic activity received much attention in the 1930s through the works of John Maynard Keynes who argued that government spending particularly increases in government spending - boosted growth by injecting purchasing power into the economy (Keynes, 1936). Keynes (1936) argued that government spendings - especially deficit spending - could provide shortterm stimulus to help end a recession or depression. From the pioneering work of Keynes (1936) on government spending, considerable efforts have been made to examine the impact of government expenditure on economic growth. Notable scholars, including Singh and Sahni (1984), Ram (1986, 1987), Ahsan, Kwan and Sahni (1992), Mitchell (2005), Irmen and Kuehnel (2008), Pham (2009), Aladejare (2013), Aigheyisi (2013), Yeoh and Stansel (2013), Osinike (2014), Fatukasi, Adebusuyi, and Ishola (2014), Rahman, Ullah, and Jebran (2015) have examined the relationship between government expenditure and economic growth but have come up with different and sometime, conflicting findings.

Economic growth refers to the increase in output of an economy's capacity to produce goods and services needed to improve the welfare of the citizens of the country (Balami, 2006). Growth is seen as a steady process which involves rising of output of goods and services in the economy. Growth is meaningful when the rate of growth is much higher than population growth because it has to lead to improvement in human welfare. Therefore, growth is seen as a steady process of increasing the productive capacity of the economy and hence, of increasing national income being characterized by higher rates of increase of per capita output and total factor productivity, especially labour productivity (Balami, 2006).

The relationship between public expenditure and economic growth has continued to generate series of debate among scholars (Akpan, 2005). Some scholars like Okwu et al, (2012) argue that increase in government expenditure on socio-economic and physical infrastructures encourages economic growth. However, some scholars like Ekpo, (1995) did not support the claim that increasing government expenditure promotes economic growth rather he assert that increasing government expenditure will slow down the overall performance of the economy.

The variations of the findings of these studies (Ram, 1986, 1987; Ahsan, Kwan \& Sahni, 1992; Mitchell, 2005; Irmen \& Kuehnel, 2008) from the theoretical literature justify the need for this study to re-examine the relationship between government expenditure and economic growth in Nigeria. This study believes that using a more robust estimation technique 
(ARDL model with rigorous diagnostic checks and test using E-view 10.0.) may yield more reliable result. The objective therefore is to re-examine the impact of government expenditure on economic growth in Nigeria from 1970 to 2017. Given the nature of the study, the researcher employed secondary source of data.

The subsequent sections of this paper are organized in five sections as follows: following the introduction (section 1), Section 2 provides review of literature. Respectively, methodology and results and discussion are treated in section 3 and 4, followed by conclusion and policy recommendations in the last section.

\section{Literature review}

Theories propounded so far on government expenditure and economic growth have shown that increase in government expenditure can lead to economic growth. Wagner's theory of government expenditure predicts that the development of an industrial economy would be accompanied by an increased share of public expenditure in gross national product (Balogun, 2013). While Keynes (1936), Njoku and Nwaeze (2014) maintain that economic growth is the outcome of government expenditure, Egbetunde and Fasanya (2013) using bounds testing (ARDL) approach showed the impact of total public spending on growth to be negative.

Musgrave-Rostow's theory holds that in the early stage of economic growth, public expenditure in the economy should be encouraged because at this stage, there exists market failures and hence there should be robust government involvement to deal with these market failures (Ogba, 1999). On the other hand, the displacement effect hypothesis propounded by Peacock and Wiseman (1961) state that government spending tends to evolve in a step-like pattern, coinciding with social upheavals, notably wars (Aigheyisi, 2014). These theories have been empirically supported by the works of Ebiringa and Charles-Anyaogu (2012), Egbetunde and Fasanya (2013), Adewara and Oloni (2012), Nwadiubu and Onuka (2015).

Empirically, D’Agostino et al. (2018) assumed that an increase in government spending might have caused a higher level of corruption in a country as well, which means that corruption might have an indirect effect on GDP growth as well. This study confirmed that government spending enhances economy growth, while large military burden and non-capital government spending reduces GDP and corruption has significant indirect impact. Meanwhile, the negative affect of government spending on economy growth was found in the countries with ineffective government (Butkiewicz \& Yanikkaya, 2018). 
Onodugo et al (2017) adopted Ordinal Least Square technique to establish the impact of public expenditures private investment on unemployment in Nigeria. The study established that public capital spending and private sector investment both in the medium to long-run served as catalyst towards reduction of unemployment. On the contrary, public recurrent expenditure was not statistically strong enough to do same as the former. The study therefore recommended, inter-alia, that: the share of public capital expenditures in Nigerian budget profile should be steadily enlarged, while the public recurrent expenditure be reduced; and there is need to enthrone healthy rivalry amongst investors by eliminating structural and institutional rigidities; and governments should design clear policy incentives to private sector investment. Ojong, Ekpo and Ogar (2016) analyzed government expenditures and its implications on the Nigerian economy using the Ordinary Least Squares technique. Findings from the analysis revealed that recurrent and aggregate expenditures have direct influence on the Nigerian economy. It recommended on the basis of the findings that governments should spend more on security as this is likely to promote investment among others.

Abu Badaer and Abu Qarn (2015) investigated the causal link between government expenditure and economic growth for Egypt, Israel and Syria. The study found bidirectional causality from government spending to economic growth but with a negative long term relationship between two variables. At the sectoral level, it was also found that military burden negatively affects economic growth for all the three countries.

Jiranyankul and Brahmasrene (2007) investigated the effect of government expenditure on economic growth in Thailand for the period 19932006 and employed standard Granger Causality test and Ordinary Least Square (OLS) method. The results showed a unidirectional causality from government expenditure to economic growth without feedback. Furthermore, estimation from the ordinary least square confirmed the strong positive impact of government expenditure on economic growth during the period of investigation.

The findings above, however, has been challenged by numerous scholars like Loizides and Vamvoukas (2015) they used data set on Greece, UK and Ireland, employed the trivariate causality to investigate the relationship between government expenditure and economic growth. The result shows that size of government expenditure causes economic growth in the three countries. Similarly, Dirukshini (2002) analysed the effect of government expenditure on economic growth in Sri Lanka over the period of 1932-2002 and applied johansen co-integration and Granger causality test. The findings of his study show that the growth of public expenditure in Sri Lanka is not directly dependent and determined by economic growth. 
Abu (2010) used panel data set for 111 developing countries including Nigeria. The author investigated recent pattern of government expenditure from 1984 to 2004 and estimated the determinants which have influenced government expenditure. The author used random effect model and find out that economic variable (debt burden, government revenue) significantly influenced government expenditure while demographic variables (population and urbanization) have been found to have significant negative association with government expenditure. The results revealed that autocratic government with military rule are not accommodative towards government expenditure.

Ekpo (2016) examined the effect of government expenditure on economic growth of Nigeria using regression model, error correction model, endogenous growth model, classical theory and Wagner's law. The study found that the investment in education and infrastructure was not highly significant but the magnitude of their impact is considerable. The study suggested that the sector to be targeted more was education and infrastructure as major drivers of economic growth and development. The study recommended that effort should be made to make agricultural sector more reliable to the Nigerian economy.

Dikeogu et al (2016) used error correction model, ordinary least square method, Keynesia theory, Wagner's law and time series data to find out the effect of government expenditure on economic growth of Nigeria, the study found out that the disaggregate public expenditure has a significant effect on economic growth. The study suggested that increase in government spending in infrastructure and investment will enhance economic growth in Nigeria.

Haque (2003) applied Keynesian theory, Johansson co integration test, granger causality test and autoregressive distributive lag approach to determine the effect of government expenditure on economic growth in Nigeria. The study found out that the government expenditure on both capital and recurrent expenditure are positively related to the economic growth in Nigeria. However, the authors assert that government should give more priority to the capital expenditure which is more productive in Nigeria.

Muritala and Taiwo (2011) examined the trends and effects of government expenditure on the growth rate of real GDP in Nigeria between 1970 and 2008 using ordinary least square techniques. The finding shows that there is a positive relationship between real GDP and government capital and recurrent expenditure. Fajinbegsi (2015) empirically investigated the relationship between government expenditure and economic growth in Nigeria. The econometric result indicated that real government capital expenditure has a significant positive influence on real output. However, the result showed that real government recurrent expenditure affects growth only by little. 
Okwu et al (2011), they investigated the effect of public spending on economic growth of Nigeria using Ordinary Least Square (OLS) for the period 1970-2009. The study did not include Granger causality test and as such, did not examine the direction of causality between public expenditure components and economic growth. In addition, some studies reviewed in Nigeria revealed unclear relationship between government expenditure and economic growth (GDP). For instance, a study by Usman et al (2011) and Adamu and Hajara (2015), D’Agostino et al. (2018) revealed positive relationship while a study by Bose (2003) revealed negative relationship.

\section{Methodology}

\subsection{Sources of Data}

Given the nature of the study, the researcher employed secondary data. The data were obtained from CBN Statistical Bulletin, 2017 and Wold Bank 2017 for variables such as; gross domestic product (GDP), capital (K), labour force (L), recurrent expenditure (REC), capital expenditure (CEP), inflation (INF) and trade openness (TOP). The study covers a sample period from 19702017.

\subsection{Data Analysis Procedure}

The study employed ARDL as its data analysis procedure with rigorous diagnostic checks and test using E-views 10.0. Thus, as the study is estimating time series data, unit root test, Phillips-Perron test, Pairwise granger causality test and co-integration tests were applied to have tested the data with a view to ascertaining the fact that the series are co-integrated and regression is not spurious as the research seeks to empirically point out the relevant variables on the effect of government expenditure on economic growth in Nigeria.

\subsection{Model Specification}

According to Bleaney et al (2001), in the neoclassical growth model, if the incentives to save or to invest in new capital are affected by fiscal policy, this alters the equilibrium capital-output ratio and therefore the level of the output path, but not its slope with transitional effects on growth as the economy moves on to its new path. The novel feature of the public-policy endogenous growth models of Barro (1990), Barro and Sala-i- Martin (1992, 1995) and Mendoza, Milesi-Ferretti, and Asea (1997) is that fiscal policy can determine both the level of the output path and the steady-state growth rate.

This study applied modified version of endogenous growth model as its theoretical framework. Endogenous growth theory assumes that the longrun rate of growth is primarily determined by endogenous variables that are internal to the system, such as human capital, innovation and investment 
capital; rather than exogenous factors where technological and scientific process are independent of economic forces. Accordingly, population growth and innovation have more impact on growth than physical capital.

The model has been adopted from Dikeogu (2016) and has been modified to be:

$$
G D P=f(K, L, C A P, R E C, I N F, T O P)-\cdots-\cdots-(1)
$$

Where:

GDP $=$ Gross domestic product

$\mathrm{K}=$ Capital

$\mathrm{L}=$ Labour force

Cap = Capital expenditure

Rec $=$ Recurrent expenditure

$\mathrm{INF}=$ Inflation

TOP $=$ Trade openness

The economic model in equation 1 can be transformed into an econometric model as natural logarithm is applied on the variables which is expressed in equation 2.

1n $G D P_{t}=\beta_{0}+\beta_{1} 1 \mathrm{n} K_{t}+\beta_{2} \ln L_{t}+\beta_{3} \ln C A P_{t}+\beta_{4} \ln R E C$,

$+\beta_{5} I N F_{t}+\beta_{6} T O P_{t}+\varepsilon_{t}-\ldots-\ldots-\cdots(2)$

Where:

$\beta_{0}$ is the coefficient of the lagged dependent variable. It provides the rate of self-perpetuating adjustment of the GDP. $\beta_{1 \ldots} \beta_{6}$ are coefficients of the explanatory variables expressed in logarithm, except for inflation and trade openness -which are used to explain the behaviour of growth in government expenditure. All other variables remain as previously defined.

\subsection{Estimation Procedure}

There are numerous techniques for the determination of stationarity of time series data, but for the purpose of this study, Augmented Dickey Fuller (ADF) test developed by Dickey and Fuller (1981) and Philips-Perron (PP) test proposed by Philips and Perron (1988) are applied because they are the most common and simple among all other techniques. Besides that, they are also robust and have the capacity to remove autocorrelation from the model. Further, the study applied the autoregressive distributive lag model (ARDL) approach to co-integration, which was popularized by Pesaran and Shin (1995), Pesaran and Smith (1997), and Pesaran, Shin and Smith (2001).

Pesaran, et al. (2001) generate and present appropriate critical values according to the number of independent variables included in the model. In this regard, the calculated f-statistics is compared with two sets of critical values developed on the ground that the explanatory variables are $\mathrm{I}(\mathrm{d})$ (where $0 \leq \mathrm{d} \leq 1)$. 


\subsubsection{ARDL Modelling}

The general conditional ARDL modelling specification for equation (3) is applied as:

$$
\begin{aligned}
& \Delta \ln G D P_{t}=\beta_{0}+\beta_{1} \ln K_{t-1}+\beta_{2} \ln L_{t-1}+\beta_{3} \ln C A P_{t-1}+\beta_{4} \ln R E C_{t-1} \\
& +\beta_{5} I N F_{t-1}+\beta_{6} T O P_{t-1}+\sum_{i=1}^{\rho} \theta_{i 1} \Delta \ln G D P_{t-1}+\sum_{i=1}^{\rho} \theta_{i 2} \Delta \ln K_{t-i}+\sum_{i=1}^{\rho} \theta_{i 3} \Delta \ln L_{t-i} \\
& +\sum_{i=1}^{p} \theta_{5 i} \Delta \ln C A P_{t-i}+\sum_{i=1}^{p} \theta_{6 i} \Delta \ln R E C_{t-i}+\sum_{i=1}^{p} \theta_{7 i} \Delta L N F_{t-i}+\sum_{i=1}^{p} \theta_{8 i} \Delta T O P_{t-i}+\varepsilon_{t}------(3)
\end{aligned}
$$

Where, $\beta_{0}$ is the drift component, $\mu_{\mathrm{t}}$, the stochastic error term; $\Delta$ is the first different operator, the parameters $\beta_{0-6}$ denote the long run parameters, while $\theta_{1-6}$ represents short run parameters of the model to be estimated through the error correction framework of ARDL. (GDP), $\ln (\mathrm{GDP})$, the natural $\log$ of gross domestic product, $\ln (\mathrm{K})$, the natural $\log$ of capital;; $\ln (\mathrm{L})$, the natural $\log$ of labour; $\ln (\mathrm{CAP})$, the natural $\log$ of capital expenditure; $\ln (\mathrm{REC})$, the natural $\log$ of recurrent expenditure; (INF), inflation and (TOP), trade openness; $\rho$, the optimal lag length and $\beta_{1-6}$ are the coefficients to be estimated in the model.

\subsubsection{Co-integration Test}

The Engle- Granger (1987) show that if there is a co-integrating vector, a simple two -step residual- based testing procedure can be employed to test for co-integration. In this case, a long run equilibrium relationship between components $\mathrm{Y}_{\mathrm{t}}$ and $\mathrm{U}_{\mathrm{t}}$ can be estimated by running $\mathrm{Y}_{1 \mathrm{t}}=\beta \mathrm{Y}_{2}+\mathrm{U}_{\mathrm{t}}$

Where $\mathrm{Y}_{2, \mathrm{t}}=\left(\mathrm{Y}_{2, \mathrm{t}} \ldots \ldots \ldots \ldots \ldots \ldots \ldots . . . . . . . . ., \mathrm{Y}, \mathrm{t}\right)$ is an $(\mathrm{K}-1) \mathrm{X} 1$ vector. To test the null hypothesis that $\mathrm{Y}_{\mathrm{t}}$ is not co-integrated, we should test whether the residuals $U_{t} I(1)$ against the alternative $U_{t} I(0)$. This can be done by any of the tests for unit root. The most commonly used is the ADF test with the constant term and without the trend term. Critical values for this test are tabulated in Mackinnon (1996).

To perform Engle-Granger test, the first steps is to run the OLS regression and the second is to test the residuals for stationarity. If the ADF test rejects the presence of unit-root in the residual series, it is concluded that future GDP, K, L, CAP, REC, INF and TOP are co-integrated. Hence, the OLS results are valid for the regression in levels as well. 


\subsubsection{Long run and Short Run Co-integration relationships}

To obtain the long run coefficient, equation 5 is specified as:

$$
\begin{aligned}
& \ln G D P_{t}=\beta_{0}+\sum_{i=0}^{p} \beta_{0} \ln K_{t-1}+\sum_{i=1}^{p_{1}} \beta_{1} \ln L_{t-1}+\sum_{i=1}^{p_{2}} \beta_{2} \ln C A P_{t-1}+\sum_{i=0}^{p_{3}} \beta_{3} \ln R E C_{t-1}
\end{aligned}
$$

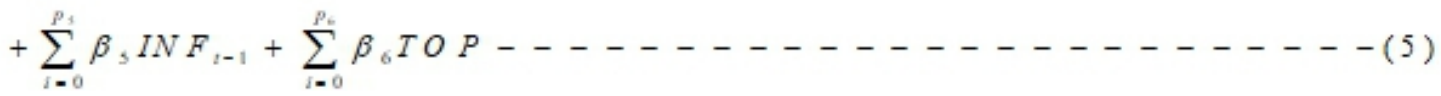

After establishing the long run co-integration, the short run model of the ARDL can be specified in equation (6):

$$
\begin{aligned}
& \Delta \ln G D P_{t-i}=\beta_{0}+\sum_{i=1}^{p} \beta_{i} \Delta \ln K_{t-i}+\sum_{i=1}^{p} \beta_{2} \ln \Delta L_{t-i}++\sum_{i=1}^{p} \beta_{3} \ln \Delta C A P_{t-i}+\sum_{i=0}^{p} \beta 4 \ln \Delta R E C_{t-i} \\
& +\sum_{i=0}^{p} \beta_{s} \Delta \ln I N F_{t-i}+\sum_{i=0}^{p} \beta_{6} \Delta T O P_{t-i}+\theta E C M_{t-i}+\varepsilon_{t}-------(6)
\end{aligned}
$$

Where $\beta_{1}-\beta_{7}$ remain as previously defined. While represents coefficients of short run dynamic to be estimated, $\theta$ represents are speed of adjustment, ECM is the error correction term and all the remaining variables remain as previously defined.

\subsubsection{Causality Test}

This test shows the existence of relationship between causality and the direction of influence. The Granger causality test is containing solely in the time series data. The causality test involved estimating the following pair of regression (Gujarati, 2004):

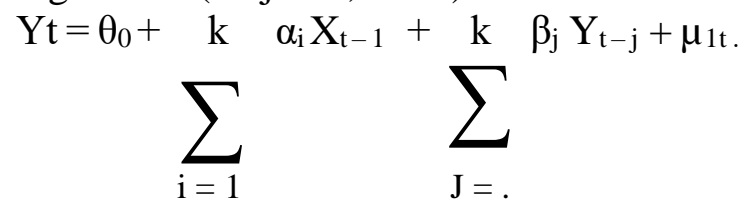

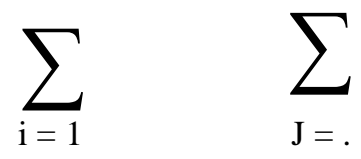

$\mathrm{X}_{\mathrm{t}=\pi_{0}}+\mathrm{k} \lambda_{\mathrm{i}} \mathrm{X}_{\mathrm{t}-1}+\mathrm{k} \delta_{\mathrm{j}} \mathrm{Y}_{\mathrm{t}-\mathrm{j}}+\mu_{2 \mathrm{t}}$

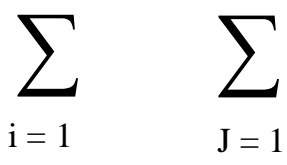

Equation "7" postulated that current $\mathrm{Y}_{\mathrm{t}}$ (holds for all independent variables used in the model) is related to past value of itself as well as that of $\mathrm{X}_{\mathrm{t}}$ (GDP as dependant variable) and equation " 8 " postulate a similar behavior for $\mathrm{X}_{\mathrm{t}}$.

Unidirectional causality from $\mathrm{X}_{\mathrm{t}}$ to $\mathrm{Y}_{\mathrm{t}}$ is indicated if the estimated coefficients of the lagged $X_{t}$ in equation ' 7 ' are statistically different from and 
the set of estimated coefficients on the lagged $Y_{t}$ in equation ' 8 ' is not statistically different from zero, thus we reject the null hypothesis that says $\mathrm{X}_{\mathrm{t}}$ does not granger cause $\mathrm{Y}_{\mathrm{t}}$. Unidirectional causality from $\mathrm{Y}_{\mathrm{t}}$ to $\mathrm{X}_{\mathrm{t}}$ occurs, if the reverse is the case. Feedback, or bidirectional causality, is said to occur when the sets of $Y_{t}$ and $X_{t}$ coefficients are statistically significant in both the regression. However, if the sets of $Y_{t}$ and $X_{t}$ coefficients are statistically insignificant, there is absence of causality between $\mathrm{Y}_{\mathrm{t}}$ and $\mathrm{X}_{\mathrm{t}}$.

\section{Results and discussion}

\subsection{Testing for Unit-Root}

The unit root tests are conducted using Augmented Dickey Fuller (ADF) and Philips-Perron (PP) tests. The result of the ADF unit root test is presented in table 1. The test regression included both intercept and trend for their level and first difference. As can be observed from table 1, when the ADF test is estimated at levels with constant and trend and intercept, none of the variables becomes stationary except inflation and labour force. This is because the value of the test statistic for the variables is less than the critical values for ADF statistic. Thus, the results indicate that the null hypothesis of nonstationary cannot be rejected at all levels except for inflation and labour force. However, all the variables become stationary after taking their first difference. Respectively, the test statistic values are greater than their critical values at 1 percent and 5 percent level of significances. Thus, the null hypothesis of nonstationary among the variables cannot be accepted, implying that the variables are stationary at order one, and inflation and labour force at order zero making it possible for the application of ARDL co-integration technique for the analysis of the impact of government expenditure on economic growth.

Table 1: ADF Unit Root Test

\begin{tabular}{|c|c|c|c|c|c|}
\hline \multirow[t]{2}{*}{ Variable } & \multicolumn{2}{|l|}{ At Level } & \multicolumn{2}{|c|}{ First Difference } & \multirow{2}{*}{$\begin{array}{l}\text { Order of } \\
\text { Integration }\end{array}$} \\
\hline & Intercept & $\begin{array}{l}\text { Trend and } \\
\text { Intercept }\end{array}$ & Intercept & $\begin{array}{l}\text { Trend and } \\
\text { Intercept }\end{array}$ & \\
\hline $\operatorname{lnGDP}$ & -0.4028 & -1.9481 & $-6.8408 * * *$ & $-6.7673 * * *$ & $\mathrm{I}(1)$ \\
\hline $\operatorname{lnCAP}$ & -1.9564 & -2.0655 & $-7.1657 * * *$ & $-7.6853 * * *$ & $\mathrm{I}(1)$ \\
\hline $\ln R E C$ & -0.3550 & -2.6076 & $-7.8415 * * *$ & $-7.7627 * * *$ & $\mathrm{I}(1)$ \\
\hline LnK & -0.7508 & -2.1643 & $-5.1112 * * *$ & $-4.8762 * * *$ & $\mathrm{I}(1)$ \\
\hline $\mathrm{LnL}$ & -0.4209 & -4.3610 & - & - & $\mathrm{I}(0)$ \\
\hline INF & $-3.4114 * * *$ & $-3.9400 * * *$ & - & - & $\mathrm{I}(0)$ \\
\hline TOP & -2.4840 & -2.1946 & -9.1990 & $-9.4568 * *$ & $\mathrm{I}(1)$ \\
\hline
\end{tabular}

Source: computed by author using E-view 10.0.

Furthermore, when PP test is conducted, the result obtained is in consonance with ADF result. Like in the case of ADF, inflation, and labour force are found to be stationary at level while other variables become 
stationary after taking their first difference at both constant and intercept and trend as reported in table 2 .

The results from both $\mathrm{ADF}$ and $\mathrm{PP}$ confirm that the variables are in order zero and order one which pave way for the application of ARDL approach to co-integration.

Table 2: Phillips- Perron Unit Root Test

\begin{tabular}{|c|c|c|c|c|c|}
\hline \multirow[t]{2}{*}{ Variable } & \multicolumn{2}{|l|}{ At Level } & \multicolumn{2}{|c|}{ First Difference } & \multirow{2}{*}{$\begin{array}{l}\text { Order of } \\
\text { Integration }\end{array}$} \\
\hline & Intercept & $\begin{array}{l}\text { Trend and } \\
\text { Intercept }\end{array}$ & Intercept & $\begin{array}{l}\text { Trend and } \\
\text { Intercept }\end{array}$ & \\
\hline $\operatorname{lnGDP}$ & -0.4019 & -2.0289 & $-6.8409 * * *$ & $-6.7673 * * *$ & $\mathrm{I}(1)$ \\
\hline $\operatorname{lnCAP}$ & -1.9839 & -2.1454 & $-7.2295 * * *$ & $-7.6304 * * *$ & $\mathrm{I}(1)$ \\
\hline $\operatorname{lnREC}$ & -0.2800 & -2.5937 & $-8.5155 * * *$ & $-8.5108 * * *$ & $\mathrm{I}(1)$ \\
\hline LnK & -1.9964 & -2.8670 & $-5.1265 * * *$ & $-4.9103 * * *$ & $\mathrm{I}(1)$ \\
\hline LnL & -0.0499 & -4.1410 & - & - & $\mathrm{I}(0)$ \\
\hline INF & $-3.2471 * * *$ & $-4.2208 * * *$ & - & - & $\mathrm{I}(0)$ \\
\hline TOP & -2.3966 & -4.0420 & - & - & $\mathrm{I}(1)$ \\
\hline
\end{tabular}

Source: computed by author using E-view 10.0.

\subsection{Bounds Test for Co-integration}

The bound test approach tests the null hypothesis that the coefficients of the lagged levels are zero. In other words, the F. statistic tests the null hypothesis of no long run co-integration relationship between the variables. Given that the study employed annual time series data, it is paramount to decide the optimal lag length of the model especially for studies with small sample data as in the case of this study. The study determines the optimal lag length of the model by specifying the longest lag and testing until the lags that are significant are found.

Thus, the result of the computed F-statistic when GDP is normalized as dependent variable in the ARDL regression is reported in table 3.

Table 3: Result of Bounds Test for Co-integration

\begin{tabular}{|l|cr|}
\hline Significance Level & Critical Values & \\
\cline { 2 - 3 } & Lower Bound & Upper Bound \\
\hline 1\% significance level & -3.43 & -4.99 \\
$5 \%$ significance level & -2.86 & -4.38 \\
$10 \%$ significance level & -2.57 & -4.04 \\
\hline
\end{tabular}

Source: Computed by author using E-view 10.0.

Table 3 depicts the result of the computed F. statistic when GDP is normalized as the dependent variable in the ARDL-OLS regression. The computed F. statistic $\mathrm{F}_{\mathrm{GDP}}(\mathrm{K}, \mathrm{L}, \mathrm{CAP}, \mathrm{REC}, \mathrm{TOP}$, and INF) is equals to 3.8174 which is higher than the upper critical values at 10 percent, 5 percent and 1 percent levels of significance indicating that there is a long run relationship between the variables. 


\subsection{Long Run Relationship of the Impact of Government Expenditure on Economic Growth}

The result of the bound test clearly shows that a long run co-integration relationship exist between the variables included in the model using ARDL (1, $0,1,1,1,1$, and 0 ) selected based on AIC. The result obtained is presented in table 4 .

Table 4: Estimated Long Run Coefficient Using ARDL Approach

\begin{tabular}{|l|l|l|}
\hline \multicolumn{3}{|l|}{$\begin{array}{l}\text { Estimated Long-Run Coefficients Using ARDL, } \\
\text { Dependent Variable: GDP }\end{array}$} \\
\hline Regressor & Coefficient $1,1,1,0)$ Approach \\
\hline Constant & $-0.3630^{* *}$ & Standard Error \\
\hline LOGK & $0.6145^{*}$ & 3.1142 \\
\hline LOGL & $-0.0990^{*}$ & 0.2284 \\
\hline LOGCAP & $-0.1203^{* *}$ & 0.8636 \\
\hline LOGREC & $0.7618^{* *}$ & 0.1666 \\
\hline INF & $-0.0047^{* * *}$ & 0.1443 \\
\hline TOP & 0.0007 & 0.0023 \\
\hline
\end{tabular}

Source: computed by author using E-view 10.0.

In the long run, the coefficient of capital stock shows a positive and significant relation with the GDP at 10 percent level of significance. This implies that a 10 percent, increase in capital Stock induces GDP by 0.61 percent. The positive coefficient of capital Stock tends to reveal that Barro (1990) endogenous growth theory holds for Nigeria. This finding is in conformity with previous studies like Richter and Paparas (2012), Kasavarajah (2012), Aregbeyen and Akpan (2013).

Furthermore, the coefficient of labour shows a negative and insignificant relationship with the GDP in the long run. This implies that labour has no impact on economic growth. This is in contrast with economic theory particularly Solow (1956) and Barro (1990) growth models. The negative nexus can be blamed on the inability of government to utilize the human resources effectively in the country.

The result also shows a negative and insignificant association between capital expenditure and GDP. This sharply contradicts economic theory as capital expenditure is expected to influence growth positively. However, this can be justified with the fact that in most cases in Nigeria, funds that are budgeted for capital projects are either misuse or stolen by politicians especially during the present democratic dispensation. This makes the spending mostly inefficacious. The result is consistent with previous studies like Nuruddeen and Usman (2010).

The coefficient of recurrent expenditure in the long run shows a positive nexus with the GDP. Although it is significant only at 1 percent level. This means that recurrent expenditure has impact on economic growth in Nigeria. A 1 unit increase in recurrent expenditure induces GDP by 0.76 
percent. The result is consistent with previous studies such as Murtala and Taiwo (2011) and Niloy, (2013).The coefficient of inflation in the long run shows a negative and insignificant influence on the GDP. This is in line with theoretical postulation that inflation increases the prices of goods and services which in turn creates price instability.

The result also depicts a positive and insignificant association between trade openness and GDP. The result is consistent with previous studies such as Akpan (2005), Rodrik (1998) and Shelton (2007).

\subsection{Short Run Relationship of the Impact of Government Expenditure on Economic Growth}

The existence of a long run co-integration relation among the variables implies the estimation of ECM to understand the dynamics of the impact of government expenditure on economic growth in the short run. The coefficient of the ECM measures the speed of adjustment to obtain equilibrium in the event of distortions in the system. Table 5 presents the result of the short run dynamic of the model of the impact of government expenditure on economic growth.

Table 5: Estimated Short Run Error Correction Model Using ARDL Approach

\begin{tabular}{|l|l|l|}
\hline $\begin{array}{l}\text { Estimated Short-Run Coefficients Using ARDL, }(1,0,1,1,1,1,0) \text { Approach } \\
\text { Dependent Variable: GDP }\end{array}$ \\
\hline Regressor & Coefficient & Standard Error \\
\hline Constant & $0.3630^{* * *}$ & 0.0539 \\
\hline D(LOGL) & $0.4504^{* * *}$ & 0.3237 \\
\hline D(LOGCAP) & 0.0445 & 0.0607 \\
\hline D(LOGREC) & $0.2204^{* *}$ & 0.0959 \\
\hline D(INF) & $0.0005^{* *}$ & 0.0009 \\
\hline D(LOGK) & $0.3171^{* *}$ & 0.1299 \\
\hline D(TOP) & $0.002^{*}$ & 0.001 \\
\hline TOP(-1) & $0.005^{* *}$ & 0.002 \\
\hline ECM (-1) & $-0.5160^{* * *}$ & 0.0922 \\
\hline $\begin{array}{l}\text { R-squared }=0.5190 \\
\text { Adjusted R-squared }=0.4604 \\
\text { Durbin Watson Statistic }=2.2116 \\
\text { F-statistic 8.8512*** }\end{array}$ \\
\hline
\end{tabular}

Source: computed by author using E-view 10.0.

The short run result reveals a negative and insignificant association between GDP and labour force in contrast with the long run result. This implies that growth in labour output has not contributed in explaining the expansion of GDP in Nigeria in the short run.

The short run result also shows that capital expenditure has a positive and insignificant effect on GDP in contrast with the long run result. 
The short run coefficient of recurrent expenditure is found to be positive but not significant which contradicts the positive and significant nexus found in the long run. Further, the coefficient of inflation in the short run is found to be positive and not significant in contrast with the long run result. The short run result also shows that capital is found to be negative and statistically significant with GDP at 5 percent level of significance in contrast with the long run result.

The short run coefficient of trade openness is found to be positive but not significant which contradicts the positive and insignificant nexus found in the long run. Numerous factors could be responsible for this. For instance, Nigeria being a consuming nation characterized with a weak productive base, its export base may not respond adequately to trade openness as well as its import bills in a shorter period.

More so, the coefficient of one year lag of trade openness is found to be positive and significant at 5 percent level. This confirms the result obtained by Nuruddeen (2010). The result could be interpreted to mean that the degree of trade openness in the previous year determines to a large extent the level of economic growth in the current period. The coefficient of the ECM which signifies the speed of adjustment of the model to equilibrium in the event of shocks, shows that 51 percent of the disequilibrium errors are corrected annually.

The result further depicts an adjusted R-square of 0.46 implying that about 46 percent of changes in GDP are explained by independent variables included in the model while the remaining 54 percent is captured by the error term. Although the value of the R-square is above average, nonetheless the low value might be associated with the fact that the political system is not captured in the empirical analysis - which have proven to be influential in previous studies (see Shelton, 2007).

\subsection{Diagnostic test}

Table 6: Model Diagnostic Tests

\begin{tabular}{|l|l|}
\hline Diagnostic Test Statistic & Statistic \\
\hline$X_{\text {Auto }}^{2}(2)$ & $1.3648[0.2695]$ \\
\hline$X_{\text {Hetro }}(2)$ & $1.0501[0.4266]$ \\
\hline$X^{2}$ Norm (2) & $1.5355[0.7650]$ \\
\hline$X_{\text {F. form }}^{2}(2)$ & $0.4129[0.5248]$ \\
\hline
\end{tabular}

Notes:

(a) $X_{\text {Auto, }}^{2} X^{2}{ }_{\text {Hetro, }} X^{2}{ }_{\text {Norm }}$ and $X^{2}{ }_{\text {Fform }}$ are statistics for test of serial correlation, heteroscedasticity, normal errors and functional form specification, and respectively.

(b) These statistics are distributed as Chi-square values with degree of freedom in parentheses. Values in parentheses [ ] are probability.

(c) Source: computed by author using E-view 10.0. 
The study conducted diagnostic tests for autocorrelation, heteroscedasticity, normality, stability and specification tests for the model which is presented in Table 6. Breusch-Godfrey LM serial correlation test is conducted and the result indicates that null hypothesis cannot be rejected as the F-statistic for test is found to be 1.3648 and with probability value of 0.2695 , indicating that there is absence of serial correlation in the model. Further, the diagnostic tests also reveal that the model is normally distributed. In the same vein, the model passes the tests for heteroscedasticity. The study also tested for model misspecification using Ramsey RESSET test and the results reveal that the model is correctly specified.

\subsection{Testing for Causality}

The essence of conducting causality test as stated earlier is to measure the causal relationship between the variables included in the model. The result of the granger causality test are reported in table 7.

Table 7: Pairwise Granger Causality Test

\begin{tabular}{|l|c|c|l|}
\hline Null Hypothesis: & \multicolumn{1}{l|}{ Obs } & F-Statistic & Prob. \\
\hline LOGK does not Granger Cause LOGGDP & 46 & 1.62412 & 0.2095 \\
\hline LOGGDP does not Granger Cause LOGK & 46 & 3.2536 & 0.0488 \\
\hline LOGL does not Granger Cause LOGGDP & 46 & 0.33619 & 0.7164 \\
\hline LOGGDP does not Granger Cause LOGL & 46 & 7.95702 & 0.0012 \\
\hline LOGCAP does not Granger Cause LOGGDP & 46 & 0.13936 & 0.8703 \\
\hline LOGGDP does not Granger Cause LOGCAP & 46 & 5.57857 & 0.0072 \\
\hline LOGREC does not Granger Cause LOGGDP & 46 & 7.96653 & 0.0012 \\
\hline LOGGDP does not Granger Cause LOGREC & 46 & 0.32396 & 0.7251 \\
\hline TOP does not Granger Cause LOGGDP & 46 & 2.54970 & 0.0904 \\
\hline LOGGDP does not Granger Cause TOP & 46 & 2.07216 & 0.1389 \\
\hline INF does not Granger Cause LOGGDP & 46 & 0.58330 & 0.5626 \\
\hline LOGGDP does not Granger Cause INF & 46 & 1.81216 & 0.1761 \\
\hline
\end{tabular}

Source: Computed by author using E-views 10.0.

Table 7 presents the pair-wise granger causality test result. It indicates that the null hypothesis that say capital stock does not granger cause GDP is rejected and the hypothesis that GDP does not granger cause capital stock is accepted at 1 percent. Thus, for the years under study, the analysis reveals the presence of a unidirectional causality from GDP and capital stock in support of Barro growth model. Furthermore, the study indicates the presence of unidirectional causality running from GDP to labour force, unidirectional causality from GDP to capital expenditure, Further; it reveals unidirectional causality from recurrent expenditure and GDP in validation of Keynesian theory. Additionally, the result of the causality test shows absence of causality between trade openness and GDP, and inflation and GDP. 


\subsection{Conclusion and Policy Recommendations}

In view of the discussion so far, the study reaches to the conclusion that there is significant relationship between GDP and recurrent expenditure and trade openness. This indicates that the empirical finding of the research rejects the null hypothesis of the research that says government recurrent expenditure has no significant impact on economic growth in Nigeria. Also, the empirical finding shows insignificant relationship between GDP and capital expenditure. This indicates that the empirical finding of the research accepts the null hypothesis of the research that says Government capital expenditure has no significant impact on economic growth in Nigeria.

Moreover, the study reveals unidirectional causality that runs from the GDP and K in support of Peacock and Wiseman (1961). Furthermore, the study indicates the presence of unidirectional causality running from GDP to labour, unidirectional causality from GDP to CAP, Further; it reveals unidirectional causality from REC and GDP in validation of Keynesian theory, thus, empirical findings of the study rejects the null hypothesis that says there is no causal relationship between government expenditure and economic growth in Nigeria. Also regression results confirmed existence of a stable long run equilibrium relationship between GDP and economic growth in Nigeria.

The study further concluded that recurrent expenditure and capital stock are significant determinants of economic growth in Nigeria whereas INF is found insignificant determinants of economic growth and also the study found no support for Wagner's law because of unidirectional causality runs from GDP to REC and CAP in support of Keynesian theory.

\subsection{Recommendations}

i. Considering the insignificant relationship between capital expenditure and economic growth (GDP), government should intensify effort to ensure that resources are properly managed and invested in productive sectors as well as diversification of the economy so as to raise the level of productive activities and most importantly raise economic growth.

ii. Government consumption spending should be well coordinated at all arms of government, to prevent 'crowding out" effect on government investment. Likewise, there should be high degree of transparency and accountability of government spending in various sectors of the economy in order to prevent the channeling of public funds into private account of government officials and workers. This can be achieved through giving autonomy to the existing anti-graft or anticorruption agencies like the Economic and Financial Crime Commission (EFCC), the Independent Corrupt Practice Commission (ICPC), and the Code of Conduct Bureau. 
iii. The existence of a relationship between government expenditure and economic growth necessitates the continued use of fiscal policy instruments to pursue macroeconomic objectives in Nigeria.

iv. Government should establish a body that will monitor the contract awarding process of capital projects closely, to guard against over estimation of project cost, abandoning and stealing of funds meant for capital projects. This will bring about a significant impact of public capital expenditure on economic growth of Nigeria.

v. Government should intensify effort to ensure resources are properly managed and invested in productive sectors so as to foster economic growth.

vi. The monetary authority should ensure that the value of the naira is protected; this will lead to appreciation of the naira and further increase economic growth.

\section{References:}

1. Abu-badar, S. and Abu Qarn A.S (2003). Government expenditures, military spending and economic growth: Causality evidence for Egypt, Isreal and Syria. Journal of Policy Modelling, 2(5), 567-583.

2. Adamu, J., and Hajara, B. (2015). Government expenditure and economic growth nexus: Empirical evidence from Nigeria (19702012). Journal of Economics and Finance, 6(2), 61-69.

3. Akpan, N. I. (2005). Government expenditure and economic growth in Nigeria, A Disaggregated Approach. CBN Review. 4(1), 25-45.

4. Balami, D. H (2006). Macroeconomics: Theory and Practice, Salawe prints, Abuja.

5. Barrow, M. (1990) Statistics for Economics, Accounting and Business Studies $2^{\text {nd }}$ Edition, Oxford

6. Barro, Robert, and Xavier Sala-i-Martin (1992). Public finance in models of economic growth, Review of Economic Studies, 5(9), 64561.

7. Badawi, A. A. (2003). Private Capital Formation and Public Investment in Sudan: Testing the Substitutability and Complementarities Hypothesis in a Growth Framework. Journal of International Development. 4(7), 25-35.

8. Bleaney, M, Gemmell, N, and Kneller, R. (2001). Economic Growth (New York: McGrew-Hill)

9. Bose, N. (2007). Public expenditure and economic growth: Dissaggregated Analysis for Developing Countries. Retrieved from http://www.ses.man.ac.u/c/cgbcr/DPCGB30 PDF.Butkiewicz, J.L. and Yanikkaya, H. (2018), "Institutions and the impact of government spending on growth", Journal of Applied Economics, 14(2), 319-341. 
10. CBN (2017). Central Bank of Nigeria Statistical Bulletin, Abuja, December 2017.

11. CBN Statistical Bulletin (Various Issues) 2008, 2010 and 2011.

12. D’Agostino, G., Dunne, P.J. and Pieroni, L. (2018), "Government spending, corruption, and economic growth", World Development, 84(8), 190-205.

13. Ekpo, A.H (1995). Public expenditure and economic growth in Nigeria, 1960-1992 Final Report, AERC, Nairobi Kenya.

14. Fajingbesi, A.A. and Odusola A.F (1999). Public expenditure and growth. A Paper Presented at a Training Programme on Fiscal Policy Planning Management in Nigeria. Organized by NCEMA.Ibadan, Oyo State. Pp. 137-180.

15. Folster, N. and Henrekson, M. (2001). Growth effects of government expenditure and taxation in rich Countries.

16. Haque, M. and D. Kim (2003). Public Investment in Transportation and Communication and Growth: A Dynamic Panel Approach, the School of Economics. Discussion Paper Series, 0324, University of Manchester.

17. Jiranyakul, K. and Brahmasrene, T. (2007). The Relationship Between Government Expenditure and Economic Growth In Thailand. Journal of Economics and Economic Education Research. 8(1), 93-102.

18. Kesavarajah, M. (2012). Wagner's law in Sri Lanka: An econometric analysis. International Scholarly Research Network, 1-9.

19. Keynes, J.M. (1936). The general theory of employment, interest and money. UK: Macmilan.

20. Muritala, T. and Taiwo A. (2011). Government Expenditure and Economic Growth. Empirical Evidence from Nigeria. European Journal of Business and Management. 3(a) Retrieved from http://mpra.vb.uni-mvenchen.de/37293.

21. Niloy, B. (2013). Public Expenditure and Economic Growth. A Disaggregated Analysis for Developing Countries. Manchester School, 75 (5).

22. Njoku, C. O., Ugwu, K. E., \& Chigbu, E. E. (2014). Government public expenditures: Effect on economic growth. (The Case of Nigeria, 1961-2013). International Journal of Research in Management, Science \& Technology 2(1), 16-29.

23. Nuruddeen, A. and Usman A. (2010). Government Expenditure and Economic Growth in Nigeria 1970-2008. A Disaggregated Analysis. Business and Economic Journal 4.

24. Ojong, C.M, Ekpo S.; Ogar A. (2016). Government Expenditure and its Implication on the Nigerian Economy, IOSR Journal of Humanities and Social Sciences (IOSR - JHSS), 21(I): 50 - 55. 
25. Okwu, A. T (2012). Effect of Public Expenditure on Economic Growth in Nigeria: A Disaggregated Time Series Analysis. International Journal of Management Sciences and Business Research, 1(7), 2-11.

26. Onodugo, V. A., Obi, K. O., Anowor, O. F., Nwonye, N. G., \& Ofoegbu, G. N. (2017). Does public spending affect unemployment in an emerging market? Risk governance \& control: Financial markets $\&$ institutions, 7(1), 32-40.

27. Pesaran, M. H. \& Smith, R. (1997). Estimating long-run relationships from dynamic heterogeneous panels. Journal of econometrics, 68(1), 79-113.

28. Pham, T. (2009). Government expenditure and economic growth: Evidence for Singapore, Hong Kong China and Malaysia. A Bachelor thesis submitted to International Bachelor of Economics and Business Economics, University Rotterdam 2008/2009.

29. Ram, R. (1986). Government size and economic growth: a new framework and some evidence from cross-section and time-series data. American Economic Review, 76, 191-203.

30. Ram, R. (1987). Wagner's hypothesis in time-series and cross-section perspectives: Evidence from 'real data' for 115 countries. The Review of Economics and Statistics, 69, 194-204.

31. Richter, C. \& Paparas, D. (2012). The validity of Wagner's law in Greece during the last 2 centuries. INFER Working Paper, 2012(2). Bonn: International Network for Economic Research.

32. Rodrik D. (1998). Why do more open economies have bigger governments? Journal of Political Economy, 22(3), 295-352.

33. Semmler, W. et al (2007). Fiscal Policy, Public Expenditure Composition, and Growth. World Bank Research Working Paper. No. 0405.

34. Shelton, C. A. (2007). The size and composition of government expenditure. Journal of Public Economics, 91, 2230-2260.

35. Singh, B., \& Sahni, B. S. (1984). Causality between public expenditure and national income. The Review of Economics and Statistics, 66, 63044.

36. Singh, J. and R. Weber, (1997). The Composition of Public Expenditure and Economic Growth: Can anything be learn from Swiss data?

37. Usman, A. (2011). Public Expenditure and Economic Growth in Nigeria. Asian Economic and Financial Review, 1(3).

38. Yeoh, M. \& Stansel, D. (2013). Is Public Expenditure Productive? Evidence from the Manufacturing Sector in U.S. Cities, 1880-1920. Cato Journal, 33(1), 1- 28. 